\title{
Metaphorical Perceptions of Folk Dances Trainers Regarding the Concept of Folk Dances
}

\author{
Ebru Olcay Karabulut ${ }^{1} \&$ Pınar Karacan Doğan ${ }^{2}$ \\ ${ }^{1}$ School of Physical Education and Sport, Ahi Evran University, Kırşehir, Turkey. \\ ${ }^{2}$ Sports Sciences Faculty, Gazi University, Ankara, Turkey. \\ Correspondence: Ebru Olcay Karabulut, School of Physical Education and Sport, Ahi Evran University, Kırşehir, \\ Turkey. E-mail: ebolka@ hotmail.com \\ Received: February 17, 2018 \\ Accepted: March 12, 2018 \\ Online Published: March 20, 2018 \\ doi:10.5430/ijhe.v7n2p84 \\ URL: https://doi.org/10.5430/ijhe.v7n2p84
}

\begin{abstract}
This research was carried out with the help of metaphor to determine the perception of folk dances trainers regarding the concept of folk dances. The study was carried out with a total of 141 folk dances trainers (85 men and 56 women), who depend on the Folk Dances Federation of Turkey.

In the study, a semi-structured interview form was used to allow participants to freely express their opinions on the specific subject. In this context, each participant was asked to write a metaphor about the concept of folk dances and to explain it. To determine the metaphorical perceptions of the concept of "folk dances" the trainers were asked to complete such clauses as "folk dances are like...." and "Because ...".

In this study, phenomenological design was used from qualitative research approaches. In the analysis of data, content analysis technique was used. Frequency and percent values were calculated. The opinions of an in-field expert and an out-of-field expert were consulted as a reliability procedure. As a result of the calculation, the reliability of the research was calculated as \%98.5.

According to the study findings, it is seen that the trainers expressed their opinions on 86 types of metaphors that are divided into 12 conceptual categories for the concept of "folk dances" and 141 views for this. The category in which maximum exists is metaphor of "Happiness, Excitement and Energy Aspect" and the most used the words were found to be "love" ( $\mathrm{f}=8)$, "ambition" ( $\mathrm{f}=5)$, "life" ( $\mathrm{f}=5)$ and "adaptation" ( $\mathrm{f}=5)$. In addition, it is observed that trainers form metaphors with many concrete tools and abstract concepts such as "labour, gain, stress ball, serotonin, culture, umbrella, pen" regarding the concept of folk dances.

As a result, it was determined that the most used metaphor for folk dances is "love" and that the category the most produced by the trainers is "happiness, excitement and energy aspect" and that the trainers have a positive perception in the metaphors produced by the "folk dances" concept.
\end{abstract}

Keywords: metaphor, metaphorical perceptions, folk dances, trainer

\section{Introduction}

When the thoughts and ways of expressing them are examined, it is observed that the individuals try to make explanations by establishing a relationship between abstract concepts and known ones. Individuals acting with their knowledge, skills and attitudes form metaphorical structures in expressing their thoughts by establishing a relationship between abstract concepts and known tangible things (Saban, Koçbeker \& Saban 2005).

Metaphor as a means of mental development was first expressed in 1980 in Lako and Johnson's work called as "Metaphors We Live By". Their idea is known as "metaphor cognitive linguistic perspective" (Beşkardeş, 2007). The concept of metaphor is considered as the art of speech until 1980 and is considered within the scope of literature and language science studies and has settled in the centre of interdisciplinary studies under the influence of the "modern metaphor theory", introduced in 1980 (Alpaslan, 2007).

The word metaphor comes from the word "metapherein" (Levine, 2005), which is a combination of Greek words "meta" (changing) and "pherein" (transmit). While the word "Metapherein" means "carry" or "transmit", Today two objects are used in the form of parallel/similar relationships between events or relationships (Draaisma, 2007).

While the word metaphor means, figure of speech, simile, figure and figurative expression, it has many different definitions. For example; according to Koç (2014) the term' metaphor "refers to the conceptual responses to these 
elements in the people's minds, which enable individuals to identify perceptions and attitudes about any tangible or abstract phenomenon, situation or process", Deant-Reed and Szokolszky (1993) define as, "indirectly describing the situation or object by using another concept or object", while Lakoff and Johnson (2005) express it as "to understand and experience a phenomenon/concept according to another phenomenon/ concept".

Metaphors are the words that correspond to many words that are meant to be expressed in everyday life and help to express the most practical, creative and permanent way of being known or wanted to be said. In this context, metaphors have a function of strengthening and deepening communication. Metaphors can be thought of as a interpretive means of communication. Because they allow opening of a new perspectives to be used to understand a complex situation and an analysis of the organizational context; Metaphors can also be defined as concrete expressions of coordination and order (Pipen, 2001).

Metaphors are used to concretize thoughts with abstract and vague emotions in the mind (Akkaya, 2012). Arnett (1999) stated that metaphors could be "a perception tool" Goldstein (2005) expressed it as the concept that could be used to redefine reality and problems by influencing our perception of situations and events.

Metaphor is a model that is mentally powerful. Because through metaphor, a certain mental schema is reflected on another mental schema by establishing a relationship between two non-identical phenomena; in this way, metaphors allow an individual to act in a way of understanding other than a certain way of understanding (Saban, 2008). Metaphors make it easier to express what you want to say in fewer words, with more emphasis. Metaphors lead the individual to think inventive, to dream, to make sense in his or her own life, and at the same time to prevent individuals from limiting them, while allowing them to find themselves in the depths of language (Tompkins \& Lawley, 2002).

Metaphors serving various purposes can sometimes be used to enrich educational environments, and complex concepts and phenomena in formal learning through analogy (Geçit \& Gençer, 2011). One of the tools that contribute to the learning of individuals in formal ways is the folk dances activities that take place in cultural and sports activities.

Folk dances, one of the most important branches of Turkish folklore, are among the elements that form the characteristic of being a nation in the face of the common feelings of the peoples. The folk dances are the most colourful and most effective means of integration in terms of formation and richness of expression among the art types that take place in all kinds of activities of society life. Due to these features, Turkish folk dances have a common sense in the feelings of our people, the formation of national consciousness in their thoughts, community solidarity and integration with the features of providing an important tool, which is considered as a common educational tool (Öngel \& Hacıbekiroğlu, 1996).

Folk dances also contribute to individual-individual, individual-community communication within the social structure. In closed societies dominated by traditional values, folk dances are used for communication and education, together with other elements. Various social values are transferred to new generations through folk dances (Sümbül, 1995).

Folk dances, which are part of social life, are formed by the socialization of the creations of individuals. Social harmony brings the necessity of individual-community communication. Folk dances contribute to the provision of harmony with individual and social functions (Artun, 2009).

The folk dances play an important role in the daily life of all nations. When the sources are examined, it is seen that the folk dances not only enter the life of society and people from religious ceremonies, but also serve as the generator of art and culture. The most important characteristics of folk dances are as follows: in folk dances, everything is played as natural and sincere; there is no compulsion; consistency, speed and dynamism, movement, rhythm and melody in some of the folk dances actually are all in one place. The player adds his sensitivity to the game. Therefore, the folk dances are lively, exciting and impressive (Ay, 1999).

The folk dances appeal to both the eye and the senses by their structural features. The folk dances that appeal to many senses and emotions have affected people in this aspect and at the same time enabled them to be directed to the folk dances. Leisure, family, culture, national clothes and local characteristics, entertainment, psychological relief, self-time, such as factors can lead individuals to the activities of folk dances.

In the light of this information, the perspective of the trainers who will contribute to the training of the players, to understand the essence of the folk dances, to internalize the meanings expressed and to develop these feelings is also important. The aim of this research is to determine how the trainers of the Turkish Folk Dances Federation conceptualized their thoughts on the concept of "folk dances" with the help of metaphor. 


\section{Method}

\subsection{Model of Research}

This study was conducted to determine the metaphors perceptions of folk dances trainers towards folk dances concept and data were collected through open-ended questionnaires. This model is preferred because qualitative research is in line with the aims of "in-depth description, interpretation and understanding of actors' perspectives" (Yıldırım \& Şimşek, 2014). Phenomenological research design was preferred in the framework of the purpose of the study. The phenomenological research design focuses on the facts that we are aware of but do not have an in-depth and detailed understanding (Creswell, 2013). In this context, content analysis was conducted on the data obtained. The main purpose of content analysis is to reach the concepts and relationships that can explain the collected data. For this purpose, the data collected must be conceptualized first, and then logically organized according to the emerging concepts, and accordingly the themes explaining the data should be determined (Yildırım \& Şimşek, 2014).

\subsection{Study Group}

The study was carried out with a total of 141 folk dances trainers ( 85 men and 56 women), who depend on the Folk Dance Federation of Turkey. For the reasons such as the need to collect detailed data about the subject, high quality of data, researchers' activities in the field of folklores, in the field of sport sciences and importance of cultural transmission in future generations through folk dances, a study group was selected according to the purposeful sampling method. In the selection of the study group, criterion sampling was used from the purposeful sampling methods (Büyüköztürk et al. 2009) which allow for the in-depth research by selecting rich situations in terms of information depending on the purpose of the study. The relevant criteria can be formed by the researcher (Yildirım \& Şimşek, 2014).

As a criterion, folk dance trainers who depend on Turkey Folk Dance Federation and their voluntarily desiring to participate in the research was taken. During the study, the participants were informed about the form on which they would express their perceptions about the concept of "folk dances".

\subsection{Data Collection Tool}

In this research, a "semi-structured interview" form was used to allow participants to freely express their ideas on a specific topic. In this context, each participant was asked to write a metaphor about the concept of folk dances and explain it. To determine the metaphoric perceptions of the concept of "folk dances" the trainers were asked to complete such clauses "folk dances are like..." and "Because..." and as a result, it was determined that the participants stated one metaphor and made a description of these metaphors.

\subsection{Data Analysis}

In this study, content analysis was used in data evaluation methods used in social studies. Content analysis is the process of defining, coding and categorizing the relevant data (Patton, 2014). Content analysis also requires that the data that resembles each other be gathered within the framework of certain concepts and themes and interpret them in a way that the reader can understand (Yıldırım \& Şimşek, 2014).

In the analysis of the research data, first of all, the answer papers of the folk dances trainers were examined, the unsuitable papers were eliminated, and the papers were compiled again. Then the answer sheets were numbered and metaphors were examined and categorized accordingly. After the validity-reliability phase, frequency calculations of metaphors were made and metaphors were interpreted. In addition, direct references to metaphors produced by the trainers of the research group are given. Trainers, in this direction, were encoded in the form of "T1, T2, T3......T 141" and these abbreviations were specified in parentheses in reference quote sentences.

In order to ensure validity and reliability, attention was paid to the validity of the research results, and to the "reporting the collected data in detail and explaining how the researcher reached the results" (Yıldırım \& Şimşek, 2014). For this purpose, the data obtained from the participants were presented to the reader through the analysis process and the direct participant statements on how the resulting codes relate to the categories. Three samples were selected for each category in the research and added to the findings section (Yıldırım \& Şimşek, 2014).

In order to ensure the reliability of research, data were analyzed by an in-field and an out-of-field expert to determine whether the conceptual categories achieved as a result of data analysis represented the themes obtained, and the codes obtained and the categories represented by the codes were compared (Y1lmaz \& Güven, 2015). Reliability of data analysis in this way was calculated by using the formula "Consensus / (Consensus + Disagreement) x 100" (Miles \& Huberman, 1994). In this study, a total of 88 metaphors were produced and 2 metaphors (shopping center, bicycles) with differences of opinion were determined. The average reliability among encoders was 98.5\% [139/ 
$(139+2) \times 100=98.5 \%$ ]. "Intra and inter coder agreement should be up in $90 \%$ range, depending on the size and range of the coding schema" (Miles \& Huberman, 1994). This result shows that the desired level of reliability has been achieved in the research.

\section{Findings}

In this part of the study, information was given about the metaphors produced by folk dances trainers about the concept of folk dances and the categories of these metaphors.

Table 1. The metaphors developed by folk dances trainers regarding the concept of folk dances

\begin{tabular}{|c|c|c|c|}
\hline Name of the Metaphor & $\mathrm{f}$ & Name of the Metaphor & $f$ \\
\hline Love & 8 & Vaccine & 1 \\
\hline Ambition & 5 & Vortex & 1 \\
\hline Life & 5 & Shopping center & 1 \\
\hline Harmony & 5 & Jukebox & 1 \\
\hline Water & 3 & Bicycle & 1 \\
\hline School & 3 & Garden & 1 \\
\hline Training tool & 3 & Points & 1 \\
\hline Folklore & 3 & Forest & 1 \\
\hline Dependency & 3 & Bee & 1 \\
\hline Honeyed & 3 & Chocolate & 1 \\
\hline Puzzle & 3 & Pomegranate & 1 \\
\hline Family & 3 & Junk food & 1 \\
\hline Poem & 3 & Delicious food & 1 \\
\hline Organ & 3 & Breakfast & 1 \\
\hline Missing & 3 & Soup & 1 \\
\hline Organization & 2 & Tea & 1 \\
\hline $\begin{array}{l}\text { The place where one earns one's } \\
\text { bread }\end{array}$ & 2 & Sky & 1 \\
\hline Transfer to generations & 2 & Mountain & 1 \\
\hline Customs & 2 & Bread & 1 \\
\hline Mirror & 2 & Knot & 1 \\
\hline Rainbow & 2 & Bud & 1 \\
\hline Mosaic & 2 & Drop & 1 \\
\hline Sun & 2 & Umbrella & 1 \\
\hline Ocean & 2 & Home & 1 \\
\hline Hand work & 2 & Mother lap & 1 \\
\hline Passion & 2 & Place for military service & 1 \\
\hline Eye & 2 & Social development & 1 \\
\hline Gold bracelet & 2 & Vitamin support & 1 \\
\hline Value & 2 & Life cabinet & 1 \\
\hline Heart & 1 & Joy of life & 1 \\
\hline Work place & 1 & Doping & 1 \\
\hline Money & 1 & Serotonin & 1 \\
\hline Profit & 1 & Meditation & 1 \\
\hline $\mathrm{Lab}$ & 1 & Stress ball & 1 \\
\hline Book & 1 & Energy source & 1 \\
\hline Roof & 1 & Beauty & 1 \\
\hline Team & 1 & Human body & 1 \\
\hline Army & 1 & Traditional life & 1 \\
\hline Pen & 1 & Travel to time & 1 \\
\hline Paper & 1 & Military service & 1 \\
\hline Light & 1 & Smoke & 1 \\
\hline Culture & 1 & Pain killer (instead of drugs) & 1 \\
\hline Alcohol & 1 & Richness & 1 \\
\hline Total & & & 141 \\
\hline
\end{tabular}


As shown in Table 1, the trainers have 86 metaphors related to the concept of "folk dances" and 141 views for this. The metaphor they use the most have been identified as follows: the words "love" ( $\mathrm{f}=8)$, respectively, and this "passion" ( $\mathrm{f}=5$ ), "life" ( $\mathrm{f}=5$ ), "adaptation" ( $\mathrm{f}=5$ ), "jigsaw" ( $\mathrm{f}=3$ ), "folklore" ( $\mathrm{F}=3$ ), "poetry" ( $\mathrm{f}=3$ ), "school" ( $\mathrm{f}=3$ ) followed by the words. It is also observed that trainers generate metaphors with many concrete tools and abstract concepts such as "labour, gain, stress ball, serotonin, culture, umbrella, pen" about the concept of "folk dances".

Table 2. Distribution of metaphors related to folk dances by categories

\begin{tabular}{|c|c|c|c|}
\hline Categories & Metaphors & $\mathrm{f}$ & $\%$ \\
\hline Integrity aspect & $\begin{array}{l}\text { Military service (1), Roof (1), Harmony (5), Army } \\
\text { (1), Team (1) }\end{array}$ & 9 & 6,39 \\
\hline Aspect of life and pleasure & $\begin{array}{l}\text { Chocolate (1), Pomegranate (1), Junk food (1), } \\
\text { Delicious food (1), Breakfast (1), Soup (1), Tea (1) }\end{array}$ & 7 & 4,97 \\
\hline Required requirements aspect & $\begin{array}{l}\text { Organ (3), Water (3), Human body (1), Heart (1), Eye } \\
(2)\end{array}$ & 10 & 7,09 \\
\hline $\begin{array}{l}\text { Aspect of happiness, excitement } \\
\text { and energy }\end{array}$ & $\begin{array}{l}\text { Love (8), Passion (5), Life (5), Longing (3), } \\
\text { Indulgence (2), Beauty (1), Serotonin (1), Meditation } \\
\text { (1), Vitamin support (1), Joy of life (1), Doping (1), } \\
\text { Energy supply (1), Bicycle (1), Stress ball (1) }\end{array}$ & 32 & 22,69 \\
\hline Protect and trust aspect & $\begin{array}{l}\text { Family (3), Mother's lap (1), Home (1), Umbrella (1), } \\
\text { place for military service (1) }\end{array}$ & 7 & 4,97 \\
\hline $\begin{array}{l}\text { The aspect requiring for labour } \\
\text { and patience }\end{array}$ & $\begin{array}{l}\text { Hand work (2), Labour (1), Knot (1), Bud (1), Drop } \\
\text { (1), Garden (1) }\end{array}$ & 7 & 4,97 \\
\hline \multirow[t]{2}{*}{ Nature components aspect } & Sun (2), Ocean (2), Whirlpool (1), Sky (1) & \multirow{2}{*}{9} & \multirow{2}{*}{6,38} \\
\hline & Mountain (1), Light (1), Bee (1) & & \\
\hline Wealth and diversity aspect & $\begin{array}{l}\text { Puzzle (3), Mosaic (2), Jukebox (1), Rainbow (2), } \\
\text { Shopping center (1), Wealth (1), Forest (1), Points } \\
\text { (1), Life cabinet (1) }\end{array}$ & 13 & 9,22 \\
\hline Dependency aspect & $\begin{array}{l}\text { Addictive substance (3), Sweet (3), Painkillers (1), } \\
\text { Cigarette (1), Adhesive paint (1), Vaccine (1) }\end{array}$ & 10 & 7,09 \\
\hline $\begin{array}{l}\text { Cultural, traditional and artistic } \\
\text { aspect }\end{array}$ & $\begin{array}{l}\text { Folklore (3), Poetry (3), Transfer to generations (2), } \\
\text { Customs (2), Mirror (2), Social development (1), } \\
\text { Travel to time (1), Culture (1), Traditional Life (1) }\end{array}$ & 16 & 11,34 \\
\hline Educational aspect & $\begin{array}{l}\text { School (3), Educational tool (3), Laboratory (1), } \\
\text { Book (1), Pencil (1), Paper (1) }\end{array}$ & 10 & 7,09 \\
\hline Economical aspect & $\begin{array}{l}\text { Organization (2), The place where one earns one's } \\
\text { bread (2), Gold bracelet (2), Workplace (1), Money } \\
\text { (1), Gain (1), Value (2) }\end{array}$ & 11 & 7,80 \\
\hline Total & & 141 & 100 \\
\hline
\end{tabular}

As shown in Table 2, the metaphors developed by the trainers on the concept of "folk dances" are given in 12 different conceptual categories. Examples of these metaphors and explanations are given below. Maximum 3 sentences are taken from each category.

\subsection{Folk Dances as an Aspect of Integrity}

It is observed that 5 metaphors were produced by 9 trainers in this category and within this scope it is emphasized that folk dances require compliance, integration and discipline.

- $\quad$ Folk Dances are like "military service". Because they teach us discipline (T. 71).

- $\quad$ Folk Dances are like "team". Because they teach us to move together (T. 82).

- $\quad$ Folk Dances are like "roof". Because Folk Dances bring people together (T. 30). 


\subsection{Folk Dances as Vital and Recreational Aspect}

It is observed that 7 different metaphors are produced by 7 trainers in this category and in this context, it is emphasized that folk dances have a positive impact on the people's lives.

- $\quad$ Folk dances are like "chocolate". Because they gives you pleasure as you eat (T. 36).

- $\quad$ Folk dances are like "pomegranate". Because when you get inside, you get as much pleasure as

you can (T. 35).

- $\quad$ Folk dances are like "a delicious meal". Because you want to eat more as you eat (T. 32).

\subsection{Folk Dances as Mandatory Requirements Aspect}

In this category, it is observed that 5 metaphors are produced by 10 trainers and in this context, the importance of the folk dances, an activity that needs to be done and the importance of the need of the individuals to do this activity are emphasized.

- $\quad$ Folk dances are like "water". Because it's found in 70\% of our lives (T. 1).

- Folk dances are like "organ". Because without them, nothing is complete (T. 62).

- Folk dances are like "heart". Because they clean our dirty thoughts and gives us life (T. 60).

3.4 Folk Dances as an Aspect of Happiness, Excitement and Energy

In this category, it is seen that 32 trainers produce 14 metaphors, and in this scope, positive emotional situations such as excitement, energy, love and happiness provided by the folk dances are emphasized.

- $\quad$ Folk dances are like "love". Because you like it more every day (T. 41).

- $\quad$ Folk dances are like "doping". Because it improves our mood with music and dance, gives positive energy (T. 58).

- $\quad$ Folk dances are like "life". Because it enhances people and makes them enjoy life (T. 57).

3.5 Folk Dances as a Protection and Reassuring Aspect

In this category, it is observed that 5 metaphors are produced by 7 trainers and in this context, the characteristics of folk dances which give confidence to individuals, make them feel in the family, give a sense of belonging are emphasized.

- Folk dances are like "family". Because hot relations are established (T. 22).

- Folk dances are like "umbrellas". Because they protect the elements it contains under it (T. 12).

- Folk dances are like "mother's lap". Because they wrap you up (T. 40).

3.6 Folk Dances as an Aspect Requiring Labor and Patience

In this category, 6 metaphors are produced by 7 trainers, and in this context, the characteristics of folk dances, such as hand works, demanding labor, and patience are emphasized.

- $\quad$ Folk dances are like "buds". Because there are too many flowers you can grow (T. 14).

- $\quad$ Folk dances are like "knots". Because when you paint it, it becomes a beautiful carpet (T. 58).

- $\quad$ Folk dances are like "drops". Because as you accumulate, it becomesa lake (T. 57).

\subsection{Folk Dances as an Aspect of Nature Elements}

In this category, it is observed that 7 metaphors are produced by 9 trainers and in this context, the characteristics of folk dances,including every element such as the sun, bright and warm, the ocean and the vortex, are emphasized.

- $\quad$ Folk dances are like "vortex". Because once you're in, you can't get out (T. 2).

- $\quad$ Folk dances are like "the ocean". Because you can see they superficially, but you'll go deeper and deeper as you move (T. 7).

Folk dances are like "sky". Because you will not get tired of seeing, watching and playing (T. 37). 


\subsection{Folk Dances as an Aspect of Wealth and Diversity}

It is observed that 9 metaphors were produced by 13 trainers in this category and within this scope, the characteristics of folk dances, such as rainbow, containing many cultural elements, music, costumes and figures and complementary features are emphasized.

-

$\bullet$

$\bullet$

\subsection{Folk Dances as an Aspect of Addiction}

In this category, it is observed that 6 metaphors are produced by 10 trainers and in this context, the characteristics of folk dances which are loved by people, generating dependency, which can not be ignored after starting are emphasized.

\section{-}

them (T.10).

desired to do it (T. 90).

Folk dances are like "tobacco". Because it's addictive as you play (T. 49).

Folk dances are like "sticky paint". Because once they get into your soul, it's hard to remove

Folk dances are like "vaccines". Because as the vaccine makes feel good, they are always

\subsection{Folk Dances as an Aspect of Cultural, Traditional and Artistic Elements}

It is observed that 10 metaphors are produced by 16 trainers in this category and in this context; the characteristics of folk dances are focused on being a cultural activity, reflecting traditions and transferring the past to the future.

from past to present (T. 70).

- $\quad$ Folk dances are like "poems". Because they develops creativity and art as they are watched, read, played (T. 60).

- $\quad$ Folk dances are like "folk science". Because they contains traditions and customs (T. 52).

\subsection{Folk Dances as Educational Aspect}

In this category, it is observed that 6 metaphors are produced by 11 trainers and in this context, the characteristics of folk dances, which include mental, emotional, physical and educational elements, guiding and enlightening individuals, are emphasized.

-

Folk dances are like "educational tools". Because they trains both our bodies and our souls (T.

78).

Folk dances are like "paper". Because paper gains valu as something is written on it, and folk dances vecome valuable as they are performed (T. 82).

want to get out (T. 43).

Folk dances are like "schools". Because you don't want to go, and when you go, you don't

\subsection{Folk Dances as an Economic Aspect}

In this context, it is observed that 7 metaphors are produced by 11 trainers and in this context, the opportunities to gain financial is emphasized for the people who play, teach and evaluate as in both music and clothing sectors.

- $\quad$ Folk dances are like "the places where one earns one's bread". Because the better you do, the more money you make (T. 73).

- $\quad$ Folk dances are like "gold bracelets". Because you may convert them into money whenever you wish and you make money. Because gold doesn't lose value (T. 56).

- $\quad$ Folk dances are like "work places". Because you earn money from their meat and milk (game, costume, music, stage order) (T. 88).

\section{Discussion, Conclusion and Recommendations}

In this study, 86 different metaphors related to folk dances are classified under 12 conceptual aspects. These categories are the Unity Aspect, Vital and Enjoyable Aspect, Compulsory Requirements Aspect, Happiness, 
Excitement and Energy Aspect, Conservation and Confidence Aspect, Labour and Patience Aspect, Nature Elements Aspect, Richness and Diversity Aspect, Dependency Aspect, Cultural, Traditional and Artistic Aspect, Educational Aspect and Economic Aspect.

In this study, when aspect content is considered separately, it is concluded that the most used metaphors for the concept of folk dances are "love" ( $\mathrm{f}=8$ ) and then "passion" ( $\mathrm{f}=5)$, "life" ( $\mathrm{f}=5)$ and "harmony" ( $\mathrm{f}=5)$, and "folklore" $(f=3)$ it has been determined that words such as "jigsaw" ( $f=3$ ), "folklore" ( $f=3$ ), "poetry" ( $f=3)$, and "school" ( $f=3$ ) are among the metaphors produced by more than one trainer. in this study, the concept of (table 1). It is also observed that trainers generate metaphors with many concrete tools and abstract concepts such as labour, gain, stress ball, serotonin, culture, umbrella, pen, home, pomegranate, money, doping etc. According to the result obtained, trainers compared folk dances to the most "love". This result may also suggest that coaches are connected to their profession by "love" and that they perceive folk dances as an indispensable value.

In his work, Gürgil (2017) found that the participants perceived folkculture as an indispensable and valuable fact for society and the individual and produced similar metaphors without working as poetry, rainbow, life / life, school / education, culture. In his work, Gürgil (2017) found that the participants perceived folkculture as an indispensable and valuable fact for society and the individual and they produced similar with our research metaphors such as poetry, rainbow, life, school / education, culture. In addition, it has been found that Ay-Thessaloniki and Fidan-Kurtdede (2013) emphasized the indispensability of cultural heritage in their work on metaphor perceptions regarding the concept of 'cultural heritage'. Concepts such as love, ambition and favour are words that express the loyalties, desires and passions of people (TDK, 2018). It can be thought that when folk dances are considered to be one of the important branches of popular culture and cultural heritage (Çakır, 2009), trainers are firmly attached to the cultures and folk dances reflecting culture and they care it therefore they use it as a metaphor.

When the metaphors produced in the study are examined extensively, it has been determined that folk dances are perceived by trainers as an activity that gives happiness, love, passion, excitement, energy to individuals. They have a very rich content, a cultural heritage and transfer to the future, educates people. As we can see, the concept of folk dances is explained by positive indicators by the participants and it is perceived in a positive way.

When the related studies were examined, similar studies were used to discuss the concept of metaphor related to folk dances and trainers. In the studies of Uslu (2013), Karacan Doğan and Yetim (2011), Öngel and Hacıbekiroğlu (1996), they found that public activities affected individuals positively. In addition, since folk dances are considered as a sports branch with cultural elements, Koç and others (2015), Yoncalık (2007), Ayyıldız (2016), Sevinç and Ergenç (2017) and Gökyürek (2016) have determined that sports activities have made positive contributions to individuals and that they have a positive perspective on sports activities of individuals.

Another finding in the study was that the most metaphorically produced category was happiness, excitement and Energy aspect $(\mathrm{f}=32)$. The metaphors produced from this category are: Cultural, Traditional and Artistic Aspect $(\mathrm{f}=16)$, Richness and Diversity Aspect ( $\mathrm{f}=13$ ), Compulsory Requirements Aspect ( $\mathrm{f}=10)$, Nature Elements Aspect $(\mathrm{f}=9)$, Dependency Aspect $(\mathrm{f}=10)$, Educational Aspect ( $\mathrm{f}=10)$, Economic Aspect ( $\mathrm{f}=11)$, Integrity Aspect ( $\mathrm{f}=9$ ), Vital and Enjoyable Aspect ( $\mathrm{f}=7$ ), Labor and Patience Aspect ( $\mathrm{f}=7$ ) and Protective and Confidence Aspect ( $\mathrm{f}=7$ ).

When the findings are evaluated in terms of the categories which are the most metaphorical, it is seen that the trainers perceive the folk dances as an activity that is joyful and exciting, which is a source of energy, which hosts rich elements, which gives joy to life, which enables cross-cultural and inter-cultural transmission, which lives customs and traditions. These concepts coincide with the scientific definitions of the concept of folk dances. For example, Eroğlu (1999) wrote the folk dances as; "reflecting the cultural values of the society to which he belongs; it is an activity that expresses an event, a joy, a sorrow; its origin is related to religion and magic; musical, performed as one person or in groups; measured, regular movements as a whole"; and Terzioğlu (1999) "defines it as an activity that consists of material and spiritual elements generated by every walks of life, from birth to death". These definitions support the "cultural traditional dimension" of folk dances.

Tezgel (2006), emphasize that the transfer of cultural heritage to the future is the most important function of education, cultural values must be taught in order for social development, socialization of the individual and membership of a society. With value education, it is possible to present the knowledge of hundreds of years of humanitarian values, which are located outside the popular culture, to the students and make decisions in the light of these accumulations. The belief that cultural heritage is an important asset lies behind the desire to be preserved and transferred to future generations. With this thought, the "educational dimension" of folk dances is emphasized. 
Korkmaz (2013) describes folk dances as "traditional games in which the inner layers are created by the strata of the people, which are based on any social, individual, or natural phenomenon shaped by their own cultural structure, that are not based on any written source, but are always internal ritual judges". When T.C. MEB (2007) stated that "As we watch our folk dances, we can see that people living in different regions of our country have characteristics that describe the struggle they are doing with nature and other living things". These expressions also support "nature elements" of folk dances.

This result can be interpreted as a positive perception of the folk dances of the trainers, they love their profession, and they assimilate the philosophy of folk dances. It is a known fact that sports activities have positive effects upon individuals as well as giving psychological effects. Because one of the functions of folk dances is treatment; children, young people and adults can express their feelings and thoughts through the folk dances. Individuals reflect their ideas that cannot be expressed openly, due to the necessities to be socially obeyed, through folk dances and thus they can relax in terms of spiritually (Sümbül, 1995).

Figures (movements) made in folk dances with music, special costumes, materials and arrangements in the stage can be considered to play an important role in making the work more enjoyable. Because the folk dances both individually and collectively meet the need for entertainment in the context of music-play. Players and viewers come together in the game environment. The enjoyment of the player's physical motion increases with the fascinating effect of the melody and rhythm. The aesthetic generated by the motion of the human body gives the spectators as much the pleasure of playing (Artun, 2009).

According to the research findings, the least metaphor was produced in the aspect of integrity. This result is thought to be quite interesting. Folk dances are a subset of folklore. The folk dances, which contain a mixture of aims and the subjects they contain, reflect the expression integrity at all stages. The folk dances that make up the whole have an important background in the historical background, in the culture they carry and in the formation of a common consciousness of people and in the shaping of the social lives of the societies. This ensures that the cultural form that the folk dances want to emphasize is presented in an artistic element (Bilget-Güçlüer, 2016).

Individuals are required to use the scene in a variety of ways while playing folk dances with music, with group, simultaneously and in a synchronized manner. This requires unity, togetherness and teamwork. In addition, individuals can meet the needs of a group by means of team members in folk dances. This sense of belonging in individuals develops confidence in themselves and the people around them. In addition, exercising for a healthy life is a priority activity. In this context, it is thought that the activities of folk dances are of importance in terms of the emergence of these feelings and the acquisition of them to the individuals.

As a result, it was determined that the most used metaphor for folk dances is "love" and that the category produced by the trainers is "happiness, excitement and energy aspect" and that the trainers have a positive perception in the metaphors produced by the "folk dances" concept.

\section{In line with this result, the following suggestions can be made;}

-Folk dances should be given more importance in physical education courses in schools.

-Support for individuals who want to play folk dances should be provided by relevant units and families.

-In order to increase folk dances activities, the institutions and organizations in this field should be supported.

\section{References}

Akkaya, E. (2012). Ortä̈gretim ögrrenci ve ögretmenlerinin okul ve ideal okul algllarının metafor yoluyla analizi. (Yayımlanmamış Yüksek Lisans Tezi). Gazi Üniversitesi, Eğitim Bilimleri Enstitüsü, Ankara.

Alpaslan, S. (2007). Sanayi ve bilgi toplumu yönetim metaforlarının karşılaştırılması. (Yayımlanmamış Yüksek Lisans Tezi). Sakarya Üniversitesi, Sosyal Bilimler Enstitüsü, Sakarya.

Arnett, R. C. (1999). Metaphorical guidance: administration as building and renovation. Journal of Educational Administration, 37(1), 80-89. https://doi.org/10.1108/09578239910253953

Artun, E. (2009). Türk Halkbilimi. 5. Baskı. İstanbul: Kitabevi.

Ay, G. (1999). Folklor Genel Bilgiler Oyun Müzik. İstanbul: Pan.

Ay-Selanik, T. \& Fidan-Kurtdede, N. (2013). Öğretmen adaylarının "kültürel miras" kavramına ilişkin metaforları. Turkish Studies, 8(12), 1135-1152. https://doi.org/10.7827/TurkishStudies.5982

Ayyıldız, T. (2016). Üniversite öğrencilerinin dans kavramına yönelik metaforik algılarının analizi. Gaziantep 
Üniversitesi Spor Bilimleri Dergisi, $1(2), \quad 13-25 . \quad$ Retrieved $\quad$ from http://dergipark.gov.tr/download/article-file/264411

Beşkardeş, S. (2007). Üstün zekalı ve özel yetenekli ögrrencilerin yabancı dil (İngilizce) öğretiminde metafor sisteminin uygulanmasl. (Yayımlanmamış Yüksek Lisans Tezi). Afyon Kocatepe Üniversitesi, Sosyal Bilimler Enstitüsü, Afyonkarahisar.

Bilget-Güçlüer, S. (2016) Adlyaman yöresi halk oyunlarının kültürel olgu ve sosyolojik ögeler açısından incelenmesi. Adıyaman Üniversitesi Sosyal Bilimler Enstitüsü, Master Thesis, Adiyaman, Türkiye. http://hdl.handle.net/123456789/258 (08.03.2018)

Büyüköztürk, Ş., Kılıç Çakmak, E., Akgün, Ö. E., Karadeniz, Ş., \& Demirel, F. (2009). Bilimsel araştırma yöntemleri. Ankara: Pegem A.

Creswell, J. W. (2013). Araştırma deseni: nicel, nitel ve karma yöntem yaklaşımları. (S. B. Demir, Çev.) Ankara: Eğiten Kitap.

Çakır, A. (2009). Tozlu Adımlar Türk Halk Oyunları Makaleler-Incelemeler. Ankara: Kültür Ajans Yayınları

Deant-Read, C. H., \& Szokolszky, A. (1993). Where do metaphors come from? Metaphor and Symbolic Activity, 8(3), 227-242. https://doi.org/10.1207/s15327868ms0803_8

Draaisma, D. (2007). Metaphors of memory: A history of ideas about the mind. (G. Koca, Çev.) İstanbul: Metis Press.

Eroğlu T. (1999). Halk Oyunları El Kitabı. İstanbul: Mars.

Geçit, Y., \& Gençer, G. (2011). Sınıf öğretmenliği 1. sınıf öğrencilerinin coğrafya algılarının metafor yoluyla belirlenmesi (Rize Üniversitesi örneği). Marmara Coğrafya Dergisi, 23, 1-19. Retrieved from http://hdl.handle.net/11424/2605

Goldstein, L. S. (2005). Becoming a teacher as a hero's journey: Using metaphor in preservice teacher education. Teacher Education Quarterly, 32(1), 7-24. Retrieved from http://www.jstor.org/stable/23478686

Gökyürek, B. (2016). An analysis of leisure attitudes of the individuals participating in dance activities and the relationship between leisure attitude and life satisfaction. International Journal of Environmental \& Science Education, 11(10), 3285-3296. Retrieved from https://files.eric.ed.gov/fulltext/EJ1114650.pdf

Gürgil, F. (2017). Öğretmen Adaylarının Halk Kültürüne Yönelik Algılarının İncelenmesi. Journal of History Culture and Art Research, 6(6), 523-541. https://doi.org/10.7596/taksad.v6i6.1214

Karacan Doğan P., \& Yetim A. A. (2011). Halk oyunlarının sosyal bütünleşmeye etkisi. Gazi Beden Eğitimi ve Spor Bilimleri Dergisi, XVI(3), 27-48. Retrieved from http://dergipark.gov.tr/download/article-file/292514

Koç, E. S. (2014). Sınıf öğretmeni adaylarının öğretmen ve öğretmenlik mesleği kavramlarına ilişkin metaforik algıları. İп̈nü Üniversitesi Eğitim Fakültesi Dergisi, 15(1), 47-72. https://doi.org/10.17679/iuefd.79408

Koç, M., Murathan F., Yetiş, Ü., Murathan T. (2015). İlköğretim 7. sınıf öğrencilerinin spor kavramına ilişkin algıları. Akademik Sosyal Araştırmalar Dergisi, 3(9), 294-303.

Korkmaz, K. (2003).“Osmaniye Halk Oyunları Hakkında Bazı Görüşler”. Osmaniye Folkloru ve Halk Kültürü Sетроzуити. (ss. 126-134)Osmaniye: Osmaniye Valiliği

Lakoff, G. \& Johnson, M. (2005). Metaforlar: hayat, anlam ve dil. (G.Y. Demir, Çev.) İstanbul: Paradigma.

Levine, P. M. (2005). Metaphors and images of classrooms. Kappa Delta Pi Record, 41(4), 172-175. https://doi.org/10.1080/00228958.2005.10532066

Miles, M. B., \& Huberman, A. M. (1994). Qualitative data analysis: An expanded sourcebook. Sage. Retrieved from http://researchtalk.com/wp-content/uploads/2014/01/Miles-Huberman-Saldana-Drawing-and-Verifying-Conclus ions.pdf

Öngel, H. B., \& Hacıbekiroğlu, E. (1996). Türk halk oyunlarl yöre oyunları ögreticisi yetiştirme kursu, halk oyunları ögretim yöntemleri ders notları. Ankara: M.E.B. Çıraklık ve Yaygın Eğitim Genel Müdürlüğü Kurslar Şubesi.

Patton, M. Q. (2014). Nitel araştırma ve değerlendirme yöntemleri. 3. Baskıdan Çeviri. (M. Bütün \& S. B. Demir, Çev.) Ankara: Pagem Akademi.

Pipen, T. (2001). Metaphors and organizational identity in the Italian puplic services. Scandinavian Journal of Management, 16, 391-409. https://doi.org/10.1016/S0956-5221(00)00014-2 
Saban, A. (2008). İlköğretim I. kademe öğretmen ve öğrencilerinin bilgi kavramına ilişkin sahip oldukları zihinsel imgeler. Ilköğretim Online, 7(2), 421-455. Retrieved from http://dergipark.ulakbim.gov.tr/ilkonline/article/download/5000038255/5000037112

Saban, A., Koçbeker, B. N., \& Saban, A. (2005). Öğretmen adaylarının öğretmen kavramına ilişkin sahip oldukları metaforlar, XIV. Eğitim Bilimleri Kongresi, Pamukkale Üniversitesi, Denizli.

Sevinç, Ö., \& Ergenç, M. (2017). Düzce Üniversitesi’nin bazı fakültelerinde öğrenim görmekte olan lisans öğrencilerinin "spor" hakkındaki metaforları. Düzce Üniversitesi Sosyal Bilimler Enstitüsü Dergisi, 7(2), 106-131. Retrieved from http://dergipark.gov.tr/dusbed/issue/33302/370718

Sümbül, M. (1995). Adana halk oyunlarının sistematik analizi. (Yayımlanmamış Yüksek Lisans Tezi). Ankara Üniversitesi, Sosyal Bilimler Enstitüsü, Ankara.

T.C. Milli Eğitim Bakanlığı (2007). MEGEP(Mesleki Eğitim Ve Öğretim Sisteminin Güçlendirilmesi Projesi) Eğlence Hizmetleri. Ankara: Milli Eğitim Bakanlığ

Terzioğlu, A. (1999). Halk oyunlarının eğitimdeki rolü. Türk Halk Oyunlarının Öğretiminde Karşılaşılan Problemler Sempozyumu Bildirileri. Ankara: Kültür Bakanlığı Halk Kültürünü Araştırma Dairesi Yayınları, 139-143.

TEZGEL, R. (2006). Yeni ilköğretim sosyal bilgiler dersi öğretim programında insan hakları ve değer eğitimi. II. Uygulamalı Etik Kongresi, Orta Doğu Teknik Üniversitesi, Ankara, 18- 20 Ekim 2006.

Tompkins, P., \& Lawley, J. (2002). The magic of metaphor. The Caroline Newsletter.

Türk Dil Kurumu Sözlüğü; www.tdk.gov.tr

Uslu, M. (2013). The impact of folk dance practices on the psycho-social development of university students. Akademik Bakış Uluslararası Hakemli Sosyal Bilimler Dergisi, 39, 1-15. Retrieved from http://dergipark.gov.tr/abuhsbd/issue/32923/365744

Yıldırım, A., \& Şimşek, H. (2014). Sosyal bilimlerde nitel araştırma yöntemleri (Genişletilmiş 9. Baskı). Ankara: Seçkin.

Yılmaz, A., \& Güven, Ö. (2015). Üstün yetenekli öğrencilerin beden eğitimi dersi ve beden eğitimi öğretmeni kavramlarına yönelik algılarının çizme yazma tekniği ile incelenmesi. Journal of Qualitative Research in Education, 3(3), 55-77. https://doi.org/10.14689/issn.2148-2624.1.3c3s3m

Yoncalık, O. (2007). Kültür ve spor bağlamında cinsiyetin "dans"a yönelik tutuma etkisi (beden eğitimi ve spor alanında öğrenim gören öğrenciler üzerinde yapılan bir analiz). Milli Eğitim Dergisi, 176, 109-118. 